now proved Murban fiold, but at the time this fact was unknown to tho prospectors. A second well was completed five years ago which, together with the sub-surface information already provided by Murban No. 1, threw more light on the character of the underground formations in this area and prompted the placing and drilling of Murban No. 3; this woll penetrated two oil-bearing formations and produced about 700 tons of oil per day on test. By October 1960, the results of those discovery wells were considered sufficiontly encouraging to justify commercial production and export. On December 31, 1963, the 36,000 ton tanker Esso Dublin discharged tho first cargo of Murban crude oil at the marine terminal of the Esso Petroleum Co.'s refinery at Milford Haven, Pem. brokeshire. As an article in the Esso Magazine (13, No. 4; Autumn 1964) states: "The discovory of this new source of oil follows hard on the heels of the important discoveries in Libya and provides not only another sizoablo addition to world proved reservos of oil, but also a further diversification of supply'.

\section{Laboratory Guide to Ion Exchange}

A USEFUL 42-page, illustrated manual ontitled Amberlite Lon Exchange Resins Laboratory Guide was published in 1964 by the Rohm and Haas Co., Philadelphite, Pa., of which a brief summary appeared in Rohm and Haas Reporter, the pcriodical of the Company $(22,3$; May-June 1964). Rohm and Haas pionoored development of ion-exchange technology in the United States and claims to be the first commercial organization in that country to produce synthetie, high-oapacity ion-cxehange resins on a large scale. The Company manufactures at present a complete range of laboratory and commercial ion exchange resins under the trademark 'Amberlite'. For laboratory uso these resing are supplied in two different grades: chemically pure and analytical roagent. More than 30 different ion-exchange resins of varying porosily and particle-sizo aro available in these grades, which are marketed by Mallinckrodt Chemical Works, St. Louis, Missouri. This manual doscribes "the many ways 'Amberlite' ion exchange resins may be used to eliminato difficult and time-consuming steps in laboratory work and explains how ion exchange operations are carried out. The manual emphasizes actual techniques for the use of ion exchange process in proparative and analytical work. ... While primarily concemed with laboratory applica. tions, the guide also reviews ways of using ion exchange resins in commercial processes". It is pointed out that these resins are exceptionally convenient to use; ofton, to make an analysis, the only equipmont requirod is a glass column containing the resin beads. Separations can be performed more rapidly and determinations made more acourately by the analyst by this ion-oxchange process than by the slower, often moro cumbersome, methods of precipitation or crystallization. Copies of this guido ean be obtained (gratis) from the Ion Exohnnge Department, Rohm and Haas Co., Philadelphia, Pa., 19105 (London subsidiary, Lennig Chemicals Ltd., 26-28 Bedford Row, London, W.C.1).

\section{Microbiological Contamination of Food}

Contamination of foods by micro-organisms does not constitute the hazard that it once did; however, new methods in processing and distributing foods are introducing new problems in food microbiology. A publication from the U.S. National Academy of Sciences-National Research Council, entitled An Evaluation of P'sblic Health Hazards from Microbiological Contamination of Foods, oxamines the prosent position (Publication No. 1195. Food Protection Committee of the Food and Nutrition Board. Pp.vi + 64. Washington, D.C.: National Academy of Sciences-National Research Council, 1964. 2 dollars). It is concluded that it would be premature to adopt legal standards but recommends several steps which should be taken to prepare the ground for their eventual adoption. It notes the increasing disparity between technical change and the level of efforts made to evaluato and control the hoalth hazurds with now products and processes. Comment is made on the poor reporting (in the United States) of the incidence of food-borno diseaso, the inconsistency of such reporting boing shown by the fact that one State repeatedly roports 30-50 per cent of all outbreaks recorded by the Public Health Servico. Dofinitions for microbiological specification, recommended microbiological limit and microbiological standard are proposed. The basic principles on which these criteria should be based are given. It is recommended that, before microbiological critoria for a food are adopted as an administrative device, standard methods of sampling and analysis of the foods in quastion should be agreed on. For this purposo, an organization similar to the Association of Official Agricultural Chemists should be formed in the field of food microbiology. Limits suggested by various workers for nine classes of foods are tabulated in an appendix together with 90 references to their source.

\section{Natural Radioactivity in Soils}

The dating of relics by radiocarbon analysis, which, in recent years, has come to be accepted as a most useful technique, is only one applicntion of the measurement of the emissions from soveral radioactive elements. Obviously the principle might be used to estimate the weathering of soils from parent materials and the goological age of soils; morcover, the radioactivity of soils is affected by fall-out contamination from atomic oxplosions. A most useful review of present knowledge on this topic has been made by $O$. Talibudeen in Soils and Fertilizers (27, No. 5. Commonwealth Bureau of Soils, Rothamsted, 1964). He doseribes tho properties of radioactive elements found in Nature and their contribution to the radioactivity of soils. About two-thirds of the total activity may be from potassium and thorium, and about 20 and 7 per cent from uranium and rubidium respeotively. Carbon-14 contributes less than 0.5 per cent, and inorganic carbonate is more active than organic carbon of the same geological age, but carbonates may have isotopic exchango with atmospheric carbon dioxide, so that there are complications in the calculation of the age of organic residues in soil. The relative amounts of radionuclides in the soil are altered by such pedological processes as leaching, oxidation and reduction, and by the levels of scsquioxides, carbonates and organic mattor, and the particle size distribution. The uranium in surface soils, for example, is related to their organic matter content, and the radium/ uranium ratio is increased by leaching. The ratio of pairs of elements may help to assess the intensity of weathering in a soil profile, the thorium/uranium ratio being a more sensitive guide to leaching than the radium/ uranium ratio. Short descriptions of the $\alpha=\beta$-and $\gamma$-assays of radioactivity are given, with notes on corrcetions and interfering unstable nuclidos. There are 9 tables of data and 2 figures of spcetra, and a comprehensive list of references.

\section{Extraction of Forest Produce}

The British Forestry Commission Booklet No. 11 reviews extraction methods in use in Great Britain and also a few that have been tried but which have proved unsuccessful (Extraction of Conifer Thinnings, By R. E. Crowther. Pp. 74+15 plates. London: H.M.S.O., 1964. 58. net). It is a timely publication because the extraction of forest produce is an important economic fuctor in forestry officiency. Extraction is a costly business and it may account for 25-75 per cent of the total costs of production, excluding the cost of growing the trees. About two-thirds of the cut from State forests is made up of coniferous thinnings and at present some 40 million hoppus $\mathrm{ft}$. of the latter are extracted in a year and the 